Abainia Sadredine
Division Productique Robotique,
Centre de Développement des
Technologies Avancées (CDTA),
Algiers,
Algeria

Ouelaa Nouredine

Laboratoire de Mécanique et Structures (LMS), Faculty of Science and Technology, Department of Mechanical, University 8 Mai 45 Guelma Algeria

Djamaa Mohamed Cherif

Laboratoire de Mécanique et Structures (LMS), Faculty of Science and Technology, Department of Mechanical, University 8 Mai 45 Guelma Algeria

\section{Modeling and Experimental Validation of Dynamic Response of the Cutting Tool in Turning Operations}

\begin{abstract}
The aim through the present paper is to calculate by analytical modelling the dynamic response of the cutting tool in turning processes, where, the general solution of the dynamic response is based on the numerical evaluation of Duhamel's integral and the integration of the measured cutting force signals into calculations. The proposed approach is a mathematical modelling of the cutting tool dynamic formulated in transverse vibrations in tangential and axial direction respectively according to the cutting speed and feedrate direction based on Rayleigh beam theory, which include the effect of rotary inertia. For this, the turning tool is modelled as a cantilever beam with a uniform cross-section, excited with tangential cutting force applied to their free-end to calculate the transverse tool displacements. To validate the analytical results, comparisons are performed against measured transverse tool displacements obtained from measured tool accelerations. Therefore, it is concluded that well agreement between results was demonstrated and was found.
\end{abstract}

Keywords: transverse vibrations, Rayleigh beam, force signal, dynamic response, Duhamel's integral, transverse tool displacement.

\section{INTRODUCTION}

In machining processes, as in turning operations; vibration is a considerable factor and a frequent problem, which influences the result of machining. In particular, tool vibration which leads to increased tool wear, cutting tool damage, and therefore short tool life, poor surface finish and unacceptable noise [1]. Globally, instability in the cutting process causes instability in the dynamic system of the machine tool [2]. Hence, the tool tip vibration measurement is a great significance for online surface topography prediction [34] and active vibration control [3]. On the other hand, tool condition monitoring can be carried out using force and vibration signals, which are very useful in automated manufacturing systems [5]. From the related researches that exist in the scientific literature various techniques have been performed by several researchers, to predict cutting force, detect vibrations and then to study the effect of the cutting conditions on the cutting force components in machining. Among these researchers, Zhang et al. [6] analysed diamond tool tips displacements in multimode high frequency obtained by numerical simulations and analytical methods. Validations are performed with cutting force signals in cutting direction. Also, Wang et al. [7] identified twin peaks of cutting force signals in the frequency domain for single-point diamond turning. Then, simulated

Received: December 2019, Accepted: February 2020

Correspondence to: Dr Abainia Sadredine

Division Productique Robotique,

CDTA-Algiers, Algeria

E-mail: s_abainia@yahoo.fr

doi:10.5937/fme2002454S

(C) Faculty of Mechanical Engineering, Belgrade. All rights reserved surface roughness obtained from tool vibration results are confronted with those measured. Liu et al. [8] calculated tool tip vibrations obtained from vibration measurements of the turret and then compared to the direct measured tool tip vibrations that show the concordance between them. It is concluded that measuring vibrations far away from the cutting area and chip evacuation zone in turning operations provided encouraging results. Moreover, Abainia et al [9] in their experimental study have selected the turning tool geometry from other newly designed and manufactured tools based on less cutting forces, less tool vibrations, and an improved surface roughness. In their work another aspect that has a great importance was explored in the cutting tool geometry selection. Skoblar et al. [10] in their paper study the dynamic transverse response of slender cantilever Euler-Bernoulli beam carrying a point mass, excited with transversal harmonic force. All calculated results are confirmed by numerical results using finite element method. As concluded by Jozwik and Mika [11] that highest vibration values in the cutting speed direction for cutting tool dynamics are caused by the highest value of the cutting force main component acting in that direction.

Comparing our research work according to the previous explored works above, the difference appears in establishing the system of equations describing movements, as for example using a system of equations described by spring-mass-damper for tool displacements calculations, or estimating the tool displacements by double integration method of measured tool acceleration signals, which differs from our utilized approach. Also, tool dynamic characteristics are determined by numerical simulation using finite element method and then reused 
into the equations of movements. Furthermore, the validation of tool tip displacements is performed against the frequency domain of the measured cutting force.

Our research work contribution and motivation in this paper is focused on the analytical formulation of the turning tool dynamic behaviour in transverse vibrations using Rayleigh beam theory, integration of only the measured cutting force signal into the general solution. The cutting tool is approximated as a short and thick beam (where their cross section is near their length dimensions), of which the rotary inertia effect is significant and happen for high-frequency vibrations. The generalized modal mass and modal stiffness are determined by applying the orthogonal conditions and integrated them into the governing differentials equations of movements to predict with accuracy tool tip displacement signals in turning process. Thus, avoiding as much as possible using multiple sensors mounted in the same machining process and be limited only to a sensor, which is of the force hence overcoming the reported problems.

In this paper, a mathematical formulation of the cutting tool dynamic behaviour during turning process in transverse vibrations is proposed. Then the general mathematical solution of the dynamic response of the turning tool is presented integrating the measured cutting force signals into calculations. Therefore, the obtained analytical and measured transverse tool displacements are compared for the validation.

\section{MATHEMATICAL FORMULATION}

Machining using machine-tools is a random phenomenon that occurred mainly between cutting tools and workpiece, hence, during turning operations the tool is subject to transverse vibrations in tangential and axial direction.

In this section, a mathematical model formulation of the cutting tool dynamic behaviour is presented, based on Rayleigh beam, including the effect of rotation of the cross-section in transverse vibrations. The cutting tool is modelled as a cantilever beam excited at its free-end by the measured cutting force component $F z$.

\subsection{Equations of cutting tool movement in trans- verse vibrations}

The turning cutting tool is modelled as a thick beam with the height to width ratio of the section is relatively low which happen for high-frequency vibrations.

The governing differentials equations of forced movement in transverse vibrations for a homogeneous and a uniform Rayleigh beam, that integrating the rotary inertia effect in the movement of a beam in two directions tangential and axial are expressed as in following [12].

$$
E I \frac{\partial^{4} w(x, t)}{\partial x^{4}}+\rho S \frac{\partial^{2} w(x, t)}{\partial t^{2}}-\rho I \frac{\partial^{4} w(x, t)}{\partial t^{2} x^{2}}=F_{z}(x, t)(1)
$$$$
E I \frac{\partial^{4} v(x, t)}{\partial x^{4}}+\rho S \frac{\partial^{2} v(x, t)}{\partial t^{2}}-\rho I \frac{\partial^{4} v(x, t)}{\partial t^{2} x^{2}}=F_{x}(x, t)
$$

The Eqs. 1 and 2 is a fourth order partial differential in space and second order in time.
With: $w(x, t)$ and $v(x, t)$ is respectively the transverse tool displacement in tangential and axial direction at a distance $x$ along the length of the beam $l$ at time $t$.

$E I \frac{\partial^{4} w(x, t)}{\partial x^{4}}$ is the bending term and $\rho I \frac{\partial^{4} w(x, t)}{\partial t^{2} x^{2}}$ is the rotary inertia term [13].

$F_{z}(x, t)$ and $F_{x}(x, t)$ are the tangential and axial force components.

$\rho$ : is mass density of the material of the beam (cutting tool).

$I$ : is the cross section moment of inertia.

$E I$ : is a uniform bending stiffness and it is constant for a uniform beam.

$\rho I$ : is the mass moment of inertia of the cross section.

$\rho S$ : is the mass per unit length.

For mathematical convenience, the above equations of movement can be rewritten in operators form as in the following form:

$$
\begin{aligned}
& \mathfrak{I}\left(\frac{\partial w^{2}}{\partial t^{2}}\right)+L(w)=F_{z}(t) \delta(x-l) \\
& L=E I \frac{d^{4}}{d x^{4}}
\end{aligned}
$$

With, $\mathfrak{I}$ and $L$ are the differential operators in space of the mass and the stiffness respectively, expressed as in follows [13]:

$$
\begin{aligned}
& \mathfrak{I}=\rho S-\rho I \frac{d^{2}}{d x^{2}} \\
& L=E I \frac{d^{4}}{d x^{4}}
\end{aligned}
$$

where $F_{z}(t) \delta(x-l)$ and $F_{x}(t) \delta(x-l)$ are the tangential and axial component of the cutting force respectively punctually applied at $x=l$.

For a cantilever beam, the applied boundary conditions are expressed in terms of the spatial function at the beam ends given as in following [12]:

- Clamped-end:

$$
x=0, \forall t: w(0, t)=0, \frac{\partial w(0, t)}{\partial x}=0
$$

- Free-end:

$$
x=l, \forall t: \frac{\partial^{2} w(l, t)}{\partial x^{2}}, E I \frac{\partial^{3} w(l, t)}{\partial x^{3}}-\rho I \frac{\partial^{3} w(l, t)}{\partial x \partial t^{2}}=0
$$

\subsection{Mathematical solution procedure}

To determine the natural frequencies and the corresponding mode shapes in the cutting speed direction, the movement expression (1) should be resolved in free transverse vibrations where $\left(F_{z}(x, t)=0\right)$, and then, it is rearranged as in following:

$$
E I \frac{\partial^{4} w(x, t)}{\partial x^{4}}+\rho S \frac{\partial^{2} w(x, t)}{\partial t^{2}}-\rho I \frac{\partial^{4} w(x, t)}{\partial t^{2} x^{2}}=0
$$


The general solution of the tangential tool transverse displacement is assumed to be as a summation of modal responses, using the separation method of variables of two functions as in following:

$$
w(x, t)=q_{n}(t), \phi_{n}(x)
$$

With $q_{n}(t)$ is the generalized coordinates and $\phi_{n}(x)$ is the mode shape function of the beam, both of $n$ order.

The resolution consists to substitute the general transverse displacement expression of the solution of. (10) into expression (9), which leads to obtain two separated ordinary differential equations (11) and (12) in time and in spatial respectively [12]:

$$
\begin{aligned}
& \frac{\partial^{2} q(t)}{\partial t^{2}}+\omega^{2} q(t)=0 \\
& E I \frac{\partial^{4} w(x)}{\partial x^{4}}-\omega^{2}\left(\rho S w(x)-\rho I \frac{\partial^{2} w(x)}{\partial x^{2}}\right)=0
\end{aligned}
$$

The solutions of (11) and (12) are assumed to be as a sinusoidal for time solution $q(\mathrm{t})$ and both sinusoidal and hyperbolic terms for the spatial solution $w(x)$ as in follow [14]:

$q(t)=d_{1} \sin \omega t+d_{2} \cos \omega t$

$\phi(x)=C_{1} \sin a x+C_{2} \cos a x+C_{3} \sinh a x+C_{4} \cosh a x$

where $\left(d_{1}, d_{2}\right)$ and $C_{i}(i=1,2,3,4)$ are constants of integration which should be determined respectively by initial conditions and the boundary conditions.

For a spatial solution of (12), replacing the expression in (14) into (12) which is satisfying the boundary conditions of (7) and (8), permitting to determine the mode shapes function as in expression (15) and the natural frequency expression as in (18); given by the following expressions [13]:

$$
\phi(x)=\cosh a_{n} x-\cos a_{n} x-\gamma_{n}\left(\sinh a_{n} x-\sin a_{n} x\right)
$$

with:

$$
\begin{aligned}
& \gamma_{n}=\frac{\cos \left(a_{n} l\right)+\cosh \left(a_{n} l\right)}{\sin \left(a_{n} l\right)+\sinh \left(a_{n} l\right)} \\
& a_{n} l=\frac{(2 n-1) \pi}{2} \\
& \omega_{n}=\left[k_{n} l\right]^{2} \sqrt{\frac{E I}{m L^{4}\left(1+\frac{I}{5 L}\left[k_{n} l\right]^{2}\right)}}
\end{aligned}
$$

where: $\omega_{n}$ are the natural frequencies of $n$ order, $S$ is section of beam, $L$ is length of beam, $E$ is young's elastic modulus, $I$ is the cross sectional area moment of inertia, $m$ is the linear mass, while the initial values of $\left[k_{n} l\right]$ are given by [14].

To calculate the forced response under tangential cutting force $F z$, the forced transverse movement (19) should be resolved utilizing the modal decomposition method. Hence, the general solution given by the tangential tool displacement $w(x, t)$ as in (20) is expressed to be as a summation of modal responses as below:

$$
\begin{gathered}
E I \frac{\partial^{4} w(x, t)}{\partial x^{4}}+\rho S \frac{\partial^{2} w(x, t)}{\partial t^{2}}-\rho I \frac{\partial^{4} w(x, t)}{\partial t^{2} x^{2}}=F_{z}(x, t) \\
w(x, t)=\sum_{n=1}^{\infty} q_{n}(t), \phi_{n}(x)
\end{gathered}
$$

The orthogonal conditions applied to the mode shapes function $\phi_{n}(x)$ in (15) for the two operators $\mathfrak{I}$ and $L$ are given in the following expressions [13]:

- For the operator of mass $\mathfrak{I}$ :

$$
\int_{0}^{l} \phi_{p}(x) \mathfrak{I} \phi_{n}(x) d x=\left\{\begin{array}{lr}
0, & \text { if } n \neq p \\
M_{n}, & \text { if }=p
\end{array}\right.
$$

- $\quad$ For operator of stiffness $L$ :

$$
\int_{0}^{l} \phi_{p}(x) L \phi_{n}(x) d x= \begin{cases}0, & \text { if } n \neq p \\ K_{n}, & \text { if }=p\end{cases}
$$

Where $M_{n}$ and $K_{n}$ are the generalized mass and stiffness respectively of $n$ mode; given by the following expressions (23) and (24) respectively [14]:

$$
\begin{gathered}
M_{n}=\int_{0}^{l} \rho S \phi_{n}^{2}(x) d x-\int_{0}^{l} \rho \frac{d^{2} \phi_{n}(x)}{d x^{2}} \phi_{n}(x) d x \\
K_{n}=\omega_{n}^{2} \int_{0}^{l} m \phi_{n}^{2}(x) d x
\end{gathered}
$$

Substituting the forced general solution (20) into (19) and applying the orthogonally conditions (21) and (22), the undamped modal equation of transverse vibrations is obtained as below:

$$
M_{n} \ddot{q}_{n}(t)+K_{n} q_{n}(t)=F_{2 n}(t), n=1,2, \ldots
$$

where $F_{z n}(t)$ : is the modal tangential force associated to the $n$ mode shape, punctually applied at $x=L$ given as in following:

$$
F_{z n}(t)=F_{z}(t) \int_{0}^{l} \phi(x) \delta(x-L) d x=F_{z}(t) \phi_{n}(L)
$$

The resolution of Eq. 25 excited by $F z$ is performed by using the operational computation and the convolution theorem. Hence, the general solution corresponding to the Duhamel's integral expression for the damped transverse vibrations is obtained in the following form:

$$
q_{n}(t)=\frac{1}{M_{n} \omega_{d}} \int_{0}^{t} F_{z n}(\tau) e^{-\xi \omega_{n}(t-\tau)} \sin \omega_{d}(t-\tau) d \tau
$$

where $F_{z n}(\tau)$ in this case is an impulsive tangential component of the cutting force and it is the only unknown obtained by experimental experiment. In the next, $\xi$ is a structural damping factor and $\omega_{d}$ is the damped natural frequency given by:

$$
\omega_{d}=\omega \sqrt{1-\xi^{2}}
$$

\subsection{Numerical evaluation of Duhamel's integral}

To calculate the general response, the integral of Duhamel (27) must be evaluated numerically using the trigonometric relationships and several integrations by 
parts, then, the expression of (27) can be rewritten under the following form:

$$
q_{n}(t)=\frac{1}{M_{n} \omega_{n}}\left\{A_{n}(t) \sin \omega_{n} t-B_{n}(t) \cos \omega_{n} t\right\}
$$

The calculation of Duhamel's integral thus requires the evaluation of the integrals $A(t)$ and $B(t)$ numerically, where for these latter are written in the following incremental form in time $t_{i}$ as follow:

$$
\begin{aligned}
& A_{n}\left(t_{i}\right)=A_{n}\left(t_{i-1}\right)+\int_{t_{i-1}}^{t_{i}} F_{z n}(\tau) \cos \omega_{n} \tau d \tau \\
& B_{n}\left(t_{i}\right)=B_{n}\left(t_{i-1}\right)+\int_{t_{i-1}}^{t_{i}} F_{z n}(\tau) \sin \omega_{n} \tau d \tau
\end{aligned}
$$

The tangential force $F_{z n}(\tau)$ can be regarded as a series of impulsive forces $F(\tau)$ acting over a very shortlived interval $d \tau$, then it can be approximated by a succession of linear segments using a linear interpolation between an each time incremental $\Delta t_{i}$ as in follow [15]:

$$
F_{z n}(\tau)=F_{z n}\left(t_{i-1}\right)+\frac{\Delta F_{z n}}{\Delta t_{i}}\left(\tau-t_{i-1}\right), t_{i-1} \leq \tau \leq t_{i}
$$

With:

$$
\Delta F_{t_{i}}=F_{z n}\left(t_{i}\right)+F_{z n}\left(t_{i-1}\right), \Delta t_{i}=t_{i}-t_{i-1}
$$

The substitution of expression (32) into (30) and (31), then their integrations yield to the integral expression (29) of the system response in which is rewritten at the time $t_{i}$ as follows:

$$
q_{n}\left(t_{i}\right)=\frac{1}{M_{n} \omega_{n}}\left\{A_{n}\left(t_{i}\right) \sin \omega_{n} t_{i}-B_{n}\left(t_{i}\right) \cos \omega_{n} t_{i}\right\}
$$

Replacing the expression given by (34) into the tangential transverse tool displacement (20) taken at $x=L$ (free-end) and for each incremental time $t_{i}$ we obtain:

$$
w\left(L, t_{i}\right)=\sum_{n=1}^{\infty} q_{n}\left(t_{i}\right) \phi_{n}(L)
$$

The resolution in the axial vibration equation is preceded with the same procedure as previously, taking account the measured axial force $F x$ into calculations of the tangential transverse tool displacements $v(x, t)$.

\section{EXPERIMENTAL VERIFICATION}

In order to demonstrate the accuracy of the proposed approach, the calculated results are verified by experiment results. For this purpose, some parts of experimental data have been exploited and reuse for this reason. Then in brief, the experimental procedure is presented in figure 1 and with the following description: Turning operations experiments were performed on a round bar form with a diameter of $80 \mathrm{~mm}$ and a cutting length of $140 \mathrm{~mm}$, with a carbon steel AISI 1045 as a workpiece material, on a universal lathe type Gallic 20 with a range of the spindle speed between 33 and 2500 $\mathrm{rpm}$. Then, the cutting tool used is fixed on a tool holder type PCLNR/L 2525M12 with a carbide insert type ISO-CNMG both from sandvik Coromant Company and with an overhang length equal to $51.2 \mathrm{~mm}$. Two types of sensors were used, a Kistler (9257B) force dynamometer with a vibration analyzer type Bruel \& Kjaer 2035 respectively for measuring the cutting force signals and tool acceleration signals. Three components of cutting forces in three mutually perpendicular directions tangential force $(F z)$ in the cutting speed direction, axial force $(F x)$ in the feed direction, and radial force $(F y)$ in the depth direction are measured in the same time with the tangential tool acceleration signals for transverse vibrations using an accelerometer type BK 4384. The sampling frequency of both force and acceleration signals was set at a sampling frequency $\mathrm{fs}=22500 \mathrm{~Hz}$. Depth of cut $a p$, feedrate $f$ and cutting speed $V c$ values are taken as variables.

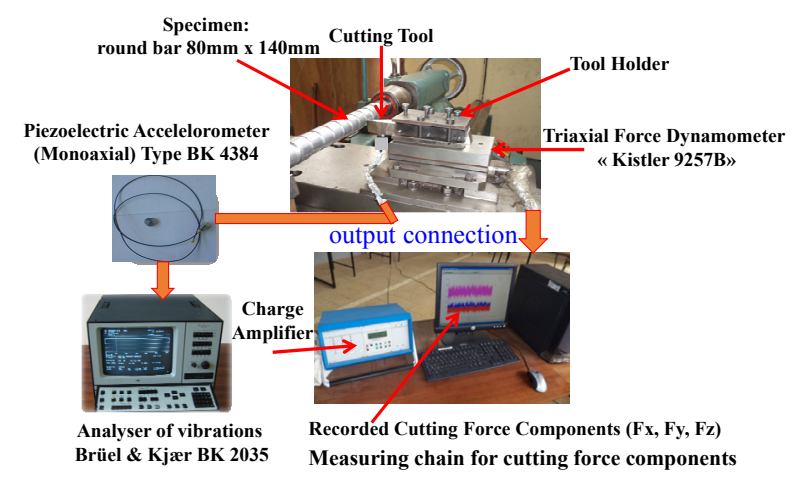

Figure 1. Experimental setup and data acquisition

\section{RESULTS AND DISCUSSION}

The experimental results are presented as three cutting force component signals in figure 2 , where the average cutting force component $F z$ is around $112.74 \mathrm{~N}$ higher than both the average axial force $F x$ (41.51) and radial force component $F y$ (42.74). Therefore $F z$ is great and a dominant component which therefore generates high tool displacements values, then a force signal $F z$ is presented in figure 3 as an example.

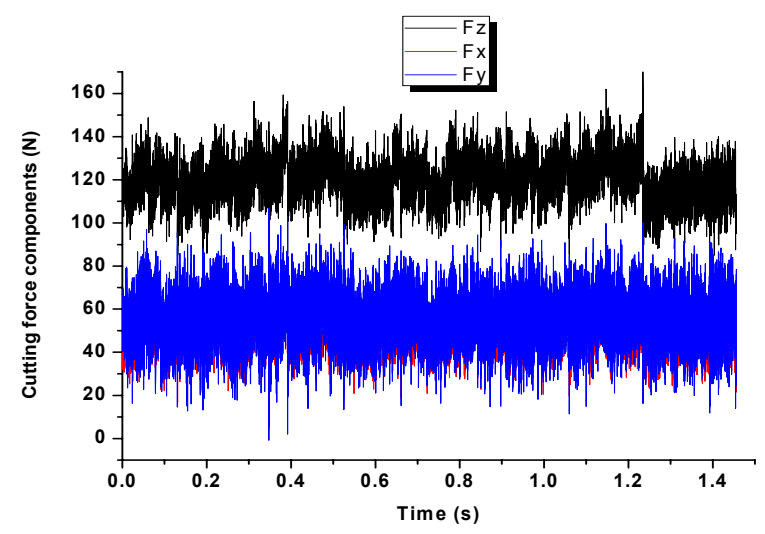

Figure 2. Cutting force component signals, for ap $=0.5 \mathrm{~mm}$, $\mathrm{f}=0.1 \mathrm{~mm} / \mathrm{rev}$ and $\mathrm{Vc}=48 \mathrm{~m} / \mathrm{min}$

To validate the obtained analytical tool displacement by the comparison in the next section, the measured tangential tool acceleration signal as in figure 5 should be converted based on the algorithm in figure 4 to calculate the corresponding tangential tool displacement signal as on figure 6 . This conversion permitted to transform an acceleration signal by calculating their spectrum acceleration using FFT function and then their 
spectrum displacement and at the end calculating the corresponding displacement signal applying inverse function of FFT on spectrum displacement.

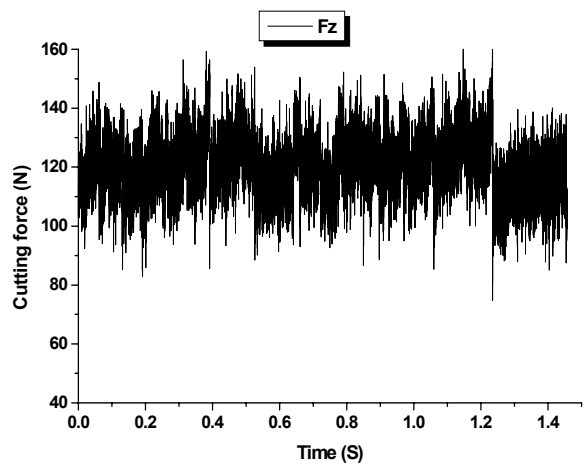

Figure 3. Tangential cutting force signal $\mathrm{Fz}$, with ap=0.5 $\mathrm{mm}, \mathrm{f}=0.1 \mathrm{~mm} / \mathrm{rev}$ and $\mathrm{Vc}=48 \mathrm{~m} / \mathrm{min}$.

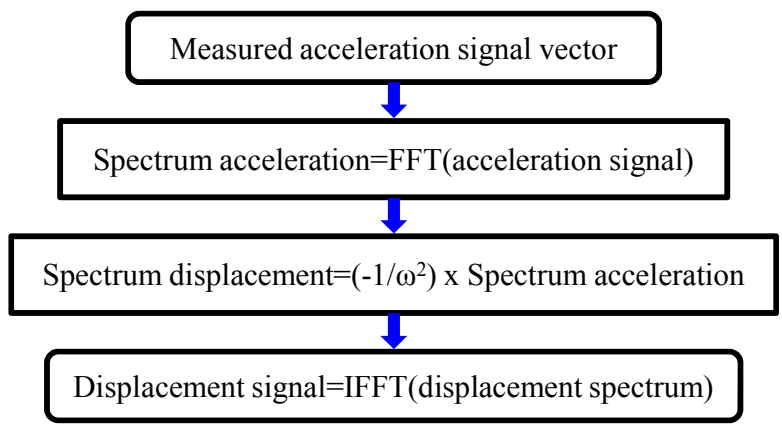

Figure 4. Algorithm of the conversion tangential tool acceleration signal to tangential tool displacement signal.

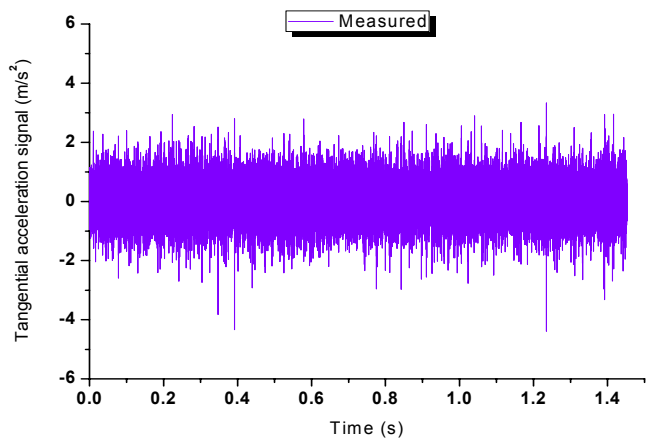

Figure 5. Tangential tool acceleration signal, with ap $=0.5$ $\mathrm{mm}, \mathrm{f}=0.1 \mathrm{~mm} / \mathrm{rev}$ and $\mathrm{Vc}=48 \mathrm{~m} / \mathrm{min}$.

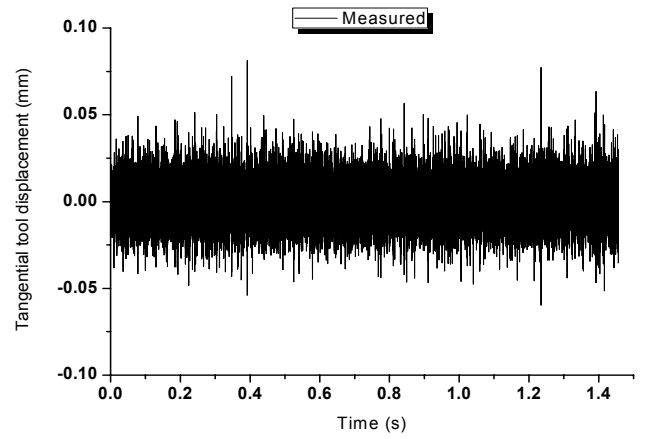

Figure 6. Corresponding tangential transverse tool displacement with $a_{p}=0.5 \mathrm{~mm}, f=0.1 \mathrm{~mm} / \mathrm{rev}$ and $V c=48 \mathrm{~m} / \mathrm{min}$.

\subsection{Results Validation}

As the tool acceleration signals are measured by a mono -axial accelerometer in cutting direction, the results confirmation are performed also in the same direction. However, to verify and to validate the tangential transverse tool displacement signal determined by this mathematical formulation, a comparison is done with that acquired by an experimental measurement as presented in Figure 7, where their amplitudes are very close and much compared. It can be concluded that well agreement between results is satisfied.

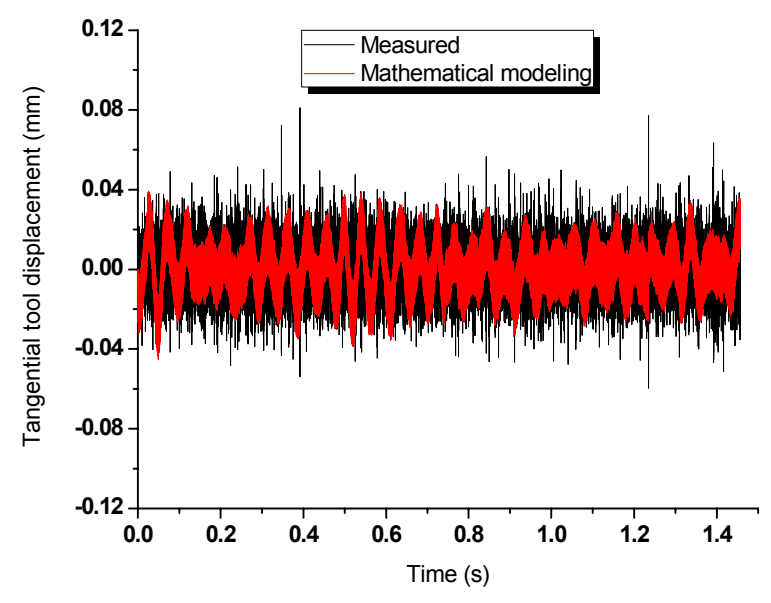

Figure 7. Comparison between mathematical and measured tangential tool displacement signal, with ap $=0.5 \mathrm{~mm}, \mathrm{f}=0.1$ $\mathrm{mm} / \mathrm{rev}$ and $\mathrm{Vc}=48 \mathrm{~m} / \mathrm{min}$.

\section{CONCLUSION}

In this proposed approach, the turning tool dynamic behaviour during turning operations is studied in transverse vibrations in time-domain by analytical modeling based on the Rayleigh beam theory, and integrating the measured cutting force into calculations in the goal to calculate the transverse tool displacement for a dynamic response. Calculated analytical transverse tool displacement is compared and validated against measured transverse tool displacement in tangential direction. A good agreement between two types of results is found. Then, the approach can be useful in ultra-precision turning especially in finishing operations of parts. Also, it can be utilized to predict and monitor the surface roughness of parts in automated machining, and extended to other machining applications.

\section{REFERENCES}

[1] Paul, P.S., Varadarajan, A.S. Robinson Gnanadurai, R.: Study on the influence of fluid application parameters on tool vibration and cutting performance during turning of hardened steel, Eng. Sci. Technol. Int. J, Vol. 19, pp. 241-253, 2016.

[2] Prasad, B.S., Babu, M.P.: Correlation between vibration amplitude and tool wear in turning: Numerical and experimental analysis. Engineering Science and Technology, an International Journal, Vol. 20, No 1, pp. 197-211, 2017.

[3] Chen, C.C., Chiang, K.T., Chou, C.C., Liao, Y.C.: The use of D-optimal design for modeling and analyzing the vibration and surface roughness in the precision turning with a diamond-cutting tool. The International Journal of Advanced Manufacturing Technology, Vol. 54, No 5-8, pp. 465-478, 2011. 
[4] Madić, M. and Radovanović, M.: Modeling and analysis of correlations between cutting parameters and cutting force components in turning AISI 1043 steel using ANN. Journal of the Brazilian Society of Mechanical Sciences and Engineering, Vol. 35, No 2, pp. 111-121, 2013.

[5] Siddhpura, M. and Paurobally, R.: A review of chatter vibration research in turning. International Journal of Machine tools and manufacture, Vol. 61, pp. 27-47, 2012.

[6] Zhang, S.J. and To, S.: A theoretical and experimental investigation into multimode tool vibration with surface generation in ultra-precision diamond turning. International Journal of Machine Tools and Manufacture, Vol. 72, pp. 32-36, 2013.

[7] Wang, H., To, S., Chan, C.Y., et al.: A theoretical and experimental investigation of the tool-tip vibration and its influence upon surface generation in single-point diamond turning. International Journal of Machine Tools and Manufacture, Vol. 50, No 3, pp. 241-252, 2010.

[8] Liu, H., Tang, S., He, S., Li, B., Mao, X. and Peng, F.: A method of measuring tool tip vibration in turning operations. The International Journal of Advanced Manufacturing Technology, Vol. 85, No 5-8, pp. 1325-1337, 2016.

[9] Abainia, S. and Ouelaa, N.: Experimental study of the combined influence of the tool geometry parameters on the cutting forces and tool vibrations, The International Journal of Advanced Manufacturing Technology, Vol. 79, No 5-8, pp. 1127-1138, 2015.

[10] Abainia, S., Ouelaa, N.: Experimental study of the combined influence of the tool geometry parameters on the cutting forces and tool vibrations, The International Journal of Advanced Manufacturing Technology, Vol. 79, No 5-8, pp. 11271138, 2015.

[11] Skoblar, A., Žigulić, R., Braut, S. and Blažević, S.: Dynamic response to harmonic transverse excitation of cantilever Euler-Bernoulli beam carrying a point mass, FME Transactions, Vol. 45, No 3, pp.367-373, 2017.
[12] Józwik, J. and Mika, D.: Diagnostics of workpiece surface condition based on cutting tool vibrations during machining. Advances in Science and Technology Research Journal, Vol. 9, No 26, pp. 57-65, 2015.

[13] Han, S. M., Benaroya, H. and Wei, T.: Dynamics of transversely vibrating beams using four engineering theories. Journal of Sound and vibration, Vol. 225, No 5, pp. 935-988, 1999.

[14] Hagedorn, P. and DasGupta, A.: Vibrations and waves in continuous mechanical systems, Wiley and Sons, Chichester, 2007.

[15] William, J. B.: Engineering Vibrations, Taylor and Francis Group, 2006.

[16] Mario, P.: Structural Dynamics: theory and computation, Springer Science, New York, 1991.

\section{МОДЕЛИРАЊЕ И ЕКСПЕРИМЕНТАЛНА ЕВАЛУАЦИЈА ДИНАМИЧКОГ ОДЗИВА РЕЗНОГ АЛАТА КОД ОБРАДЕ НА СТРУГУ}

\section{А. Садредин, К. Нуредин, Ђ.М. Шериф}

Циљ рада је израчунавање динамичког одзива резног алата код обраде на стругу применом аналитичког моделирања. Динамички одзив се базира на нумеричкој евалуацији Духамеловог интеграла и интегрисањем измерених сигнала силе резања у израчунавања. Предложени метод представља математичко моделирање динамике резног алата код попречних вибрација у тангенцијалном и аксијалном правцу, према брзини резања и правца помоћног кретања, базираном на Рајлијевој теорији греде која укључује и утицај ротацијске инерције. Зато је резни алат за обраду на стругу моделиран као конзолна греда са униформним попречним пресеком, која побуђује тангенцијалну силу резања а која дејствује на слободном крају, што омогућава израчунавање попречних помераја алата. Резултати анализе су евалуирани упоређивањем са измереним попречним померајима алата добијеним мерењем убрзања алата. Утврђено је добро слагање између добијених резултата. 